\title{
Biotech Approaches to Overcome the Limitations of Using Transgenic Plants in Organic Farming
}

\author{
Luca Lombardo ${ }^{1, *}$ and Samanta Zelasco ${ }^{2}$ \\ 1 Institute for Sustainable Plant Protection, Italian National Research Council, 80055 Portici, Italy \\ 2 Olive Growing and Olive Oil Industry Research Centre, Agricultural Research Council, 87036 Rende, Italy; \\ samanta.zelasco@crea.gov.it \\ * Correspondence: lombluca@yahoo.it; Tel.: +39-081-253-9337 \\ Academic Editor: Gerhart U. Ryffel \\ Received: 16 March 2016; Accepted: 18 May 2016; Published: 20 May 2016
}

\begin{abstract}
Organic farming prohibits the use of genetically modified organisms (GMOs) inasmuch as their genetic material has been altered in a way that does not occur naturally. In actual fact, there is a conventional identity between GMOs and transgenic organisms, so that genetic modification methods such as somatic hybridization and mutagenesis are equalized to conventional breeding. A loophole in this system is represented by more or less innovative genetic engineering approaches under regulatory discussion, such as cisgenesis, oligonucleotide-directed mutagenesis, and antisense technologies, that are redefining the concept of GMOs and might circumvent the requirements of the GMO legislation and, indirectly, of organic farming.
\end{abstract}

Keywords: organic farming; cisgenesis; genome editing; GMO regulations

\section{Introduction}

Organic farming (OF) systems are conceived to produce food through the integration of cultural, biological, and mechanical practices aimed at preserving natural resources, biodiversity animal welfare, and eventually human health. The production chain is guided by the choice and employment of (mostly) natural resources obtained using natural processes. As GMOs are organisms "with the exception of human beings, in which the genetic material has been altered in a way that does not occur naturally by mating and/or natural recombination" (Directive 2001/18/EC [1]) and many concerns have been raised about their safety and impact on human health and the environment, the use of genetically engineered crops and products obtained from or by GMOs are prohibited by all the organic farming legislations and standards worldwide. Regardless of the merits of the concerns and of what should be considered "natural" (Charles Darwin coined the term "artificial selection" in the 1859 first edition of On the Origin of Species to describe the "selective breeding" or conventional breeding), this ban could be eluded by the biotech approaches that might fall outside the scope of the current process-oriented (only Canada has a product-based regulation system on GMOs.) GMOs regulations. In fact, if the definition of GMOs implies the employment of modern biotechnologies to obtain a novel combination of genetic material (as written in the Cartagena Protocol on Biosafety to the Convention on Biological Diversity-conceptually-the product of modern biotechnologies presenting no novel combination of genetic material could be treated as non-GM, resulting therefore acceptable for organic farming productions, whereas plants engineered to tolerate herbicides in any case would remain outside the provisions of $\mathrm{OF}$.

Some of the most promising techniques still under evaluation will be discussed in the following paragraphs. 


\section{Cisgenesis and Intragenesis}

Recombinant DNA (rDNA) technology allows one to engineer plants with one or more sense genes to induce the expression of additional valuable traits, dramatically accelerating the transfer of alleles between compatible species or between species that are impossible or difficult to cross. Depending on the nature and the origin of the inserted DNA segment, rDNA technology has been exploited to produce transgenic, cisgenic, and intragenic plants. In transgenic plants, the introduced gene(s) derives from an organism of a different species. Cisgenesis implies the insertion of a whole gene, as it includes introns and controlling sequences deriving from an organism of identical or sexually compatible species. An exception is represented by the border sequences that flank the cisgene, whereas cisgenic plants produced via Agrobacterium-mediated transformation are likely to present T-DNA borders from the bacterium (EFSA, 2012 [2]). Similarly, intragenesis provides the use of donor and recipient plants belonging to the same species, but the inserted gene(s) derives from the in vitro combination of different functional genetic elements such as promoters, coding regions, and terminator sequences; the coding region could lack introns if cDNA or fragments of genes are used. These technologies have been successfully exploited to obtain the cisgenic Arctic ${ }^{\mathrm{TM}}$ "Golden Delicious" and "Granny Smith" apples (Okanagan Specialty Fruits Inc., Summerland, BC, Canada), a cisgenic alfalfa with altered lignin production (Monsanto) and the intragenic potatoes of the Innate ${ }^{\mathrm{TM}}$ line (J.R. Simplot Co., Boise, ID, USA) that are currently cultivated for commercial purposes and in a series of encouraging experiments with different crops. (Holme et al., 2013 and the bibliography therein [3]). Nevertheless, only particular cases of intragenesis (hardly distinguishable from cisgenesis) could lead to new combinations of genetic material that occur naturally so that crops obtained through this approach are unlikely to be accepted as non-GM. Conversely, as a new cisgenic genotype could be theoretically obtained through conventional breeding because of the use of unmodified genetic material from the same species, several authors (Schouten et al. 2006; Rommens et al. 2007; Hou et al., 2014 [4-6]) have argued that cisgenesis should be excluded from the provisions of the current GMO regulations. However, GMO regulations worldwide are slightly different and interpretation is often a matter of nuances. For example, in the Australian Gene Technology Regulations (2001 [7]), it is stated that "a mutant organism in which the mutational event did not involve the introduction of any foreign nucleic acid" is not to be considered as GM, thus indirectly green-lighting the use of cisgenic crops (whereas only the inserted construct is without T-DNA borders) in organic farming. Under Canadian law, cisgenic crops are assimilated to new plant varieties but remain within the classification of GMOs and are excluded from OF provisions. Similarly, the report by the European Food Safety Authority (EFSA, 2012 [2]), while admitting that cisgenic (and intragenic) plants should be generally regulated less strictly than transgenic plants on a case-by-case basis, basically equates the two approaches, relegating cisgenic crops in the enclosure of GMOs, insofar as a new resolution is shortly expected. The major concern that has led to this equalization, even in all the other countries apart from Australia, is that in general it is not possible to predict a priori into which position of the host plant genome the "cisgene" is going to be inserted; however, to be effective, the insertion has to occur in active regions of the DNA. Therefore, the insertion could occur even in the middle of another gene and thus may alter the expression of the same or of adjacent genes, producing variations that are difficult to predict (Van Bueren et al., 2007 [8]). In addition, a technical obstacle to the employment of cisgenesis in OF is represented by the possible presence of the T-DNA borders. However in the next few months or years, a review of the existing regulations is very likely and to some extent desirable, taking into account the potential of these new techniques.

A further issue to consider is that pollen drift and introgression of genetically modified pollen are fundamentally possible over large distances in agriculture. This, and the constant increase of GM acreage (James, 2014 [9]), will make it difficult to ensure the absolute (100\%) purity of organic crops in the future, which is a mandatory requirement of organic farming, whereas only the European Union has a $0.9 \%$ threshold for the presence of GMO content, below which, products can still be labeled organic. In this sense, by the fall of 2015, The GM Contamination Register [10] by GeneWatch UK and 
Greenpeace International has recorded 434 incidents of contamination arising from the intentional or accidental release of GM organisms across 63 countries since 1997. Nevertheless, where introgression of cisgenes occurs, especially via pollen from cisgenic crops with genes introduced from the same species without T-DNA borders and other foreign DNA, the detection of the contamination would be at least problematic and would add further doubts on the classification of the host plants. Paradoxically, this is the issue that could most worry seed companies that have a vested interest that the newly added valuable trait is not freely dispersed, so that event-specific tests (i.e., PCR across the regions flanking the insertion site; Holst-Jensen et al., 2012 [11]) should be conceived.

\section{Genome Editing}

\subsection{Genome Editing with Engineered Nucleases (GEEN)}

This technology relies on the use of hybrid-engineered nucleases with a sequence-specific DNA-binding domain, fused to a non-specific DNA cleavage module, able to induce targeted DNA double-strand breaks (DSBs). This stimulates the error-prone cellular mechanisms of DNA reparation by non-homologous end-joining (NHEJ) and homologous recombination (HR) in order to knock out specific genes or to insert a new DNA fragment in the desired position (Peng et al., 2014 [12]). Sequence-specific nucleases include hybrid meganucleases, zinc finger nucleases (ZFNs), transcription activator like effectors nucleases (TALENs), and the CRISPR/Cas9 system. In hybrid meganucleases, the binding and the cleavage domains are incorporated together in a complex and quite rigid molecule, narrowing the range of possible modifications. This makes meganucleases less suitable to bind any target sequence. TALENs and ZFNs present "assemblable" modular DNA binding sites with a DNA cleavage module derived from the restriction enzyme Fok I. In TALENs, up to 18 modules are fused together, whereas each module binds a single nucleotide, while ZFNs are generally formed by three or four modules; each module comprises a zinc finger structure (Urnov et al., 2010 [13]) recognizing three or four adjacent nucleotides. The CRISPR (Clustered Regularly Interspaced Short Palindromic Repeats)/Cas9 editing tool, in its most commonly used embodiment-even called RNA-guided endonucleases (RGENs) - provides the use of a hairpin-specific RNA guide (gRNA) that carries a particular Cas9 nuclease for the sequence-complementary cleavage of DNA (Jiang et al., 2013 [14]). Inheritable permanent modifications have been obtained in tobacco (Zhang et al. 2013 [15]), rice (Xie and Yang, 2013 [16]), sorghum (Jiang et al., 2013 [14]), and wheat (Upadhyay et al., 2013 [17]).

These approaches provide the insertion of a transgene that codes for the engineered nuclease responsible for the subsequent modification, but recently Woo et al. (2015 [18]) demonstrated that it is possible to use these molecular scissors without introducing foreign DNA into plant cells by delivering preassembled Cas9 protein-gRNA ribonucleoproteins (RNPs). The plants obtained through this method, albeit carrying the desired targeted mutation (gene inactivation), are not genetically modified at any stage of their production and therefore suitable for organic farming conditions. In this sense, on 13 April 2016, the USDA Animal and Plant Health Inspection Service (APHIS) concluded that the CRISPR/Cas9-engineered white button mushroom (Agaricus bisporus) to resist browning, developed by the plant pathologist Yinong Yang at Pennsylvania State University, does not contain any introduced genetic material and therefore will not be regulated (USDA, 2016 [19]). Predictably, this decision will lead to massive investments in this technology in the next few years.

Furthermore, the possibility of inserting a cisgene in a predetermined position via this method would allow one to overcome the previously described limits of cisgenesis employment in OF.

\subsection{Oligonucleotide-Directed Mutagenesis (ODM)}

The term oligonucleotide-directed mutagenesis encloses several differently dubbed techniques such as chimeraplasty, targeted nucleotide exchange, chimeric oligonucleotide-dependent mismatch repair, etc. used to correct or to introduce site-specific mutation into genes. Mutagenesis is induced through the introduction of a chemically synthesized complementary chimeric DNA/RNA or 
DNA/DNA oligonucleotide (20-100 nucleotides in size) as well as single-stranded DNA, RNA, or triple-helix-forming oligonucleotides, designed to have one or more bases that do not pair with the endogenous gene sequence (Breyer et al. 2009 and bibliography therein [20]). The helical distortion induced by the mismatch in the homology-directed pairing between the oligonucleotide and the DNA of the target region is subsequently recognized by the cell's DNA repair machinery and corrected (base substitution, addition, or deletion) using the DNA sequence of the chimera as a template; eventually, the oligonucleotide is naturally degraded (Sauer et al., 2016 [21]). The targeted gene mutation is stable and transmitted to subsequent generations (Zhu et al., 2000 [22]), albeit the overall efficiency of the technique is quite low (Breyer et al. 2009 [20]). Insofar as oligonucleotides can be directly introduced via electroporation or particle bombardment, there is no foreign material integrated into the plant that therefore cannot be distinguishable from the "natural" counterpart. To this extent, in its 2006 advisory report 'New Techniques in Plant Biotechnology' the Dutch Commissie Genetische Modificatie (COGEM) [23] stated that "specific mutagenesis with oligonucleotides [is] a form of 'traditional' mutagenesis. It should therefore be exempt from GMO legislation and regulations." In support of this thesis, Food Standards Australia New Zealand (FSANZ) (2013 [24]) concluded that "ODM is not considered to be a recombinant-DNA technique" and "is conceptually no different to traditional mutagenesis." In 2004, the USDA determined that the sulfonylurea herbicide-tolerant GM canola, branded SU Canola ${ }^{\mathrm{TM}}$, developed by the agritech company Cibus LLC through a form of ODM dubbed Rapid Trait Development System (RTDS) is a modern form of mutagenesis and should not be regulated by state or federal agencies. Similarly, UK's Advisory Committee on Releases to the Environment (ACRE) at Defra (Department for Environment, Food and Rural Affairs) published a report in 2011 [25] stating that "ACRE considers that herbicide tolerant (HT) oilseed rape plants produced by Cibus LLC have been developed using a form of mutagenesis. It considers that this technique does not involve the use of recombinant nucleic acid molecules. Consequently, the HT oilseed rape plants could be excluded from the GMO Deliberate Release legislation in accordance with Annex 1B of Directive 2001/18/EC." Eventually, on 5 February 2015, the German Federal Office of Consumer Protection and Food Safety (BVL) decided that the CIBUS rapeseed are not classified as genetically engineered (GE) organisms according to the definition in the Genetic Engineering Act [26].

Considering that plants developed via mutagenesis are allowed by any nation's OF standards, it is easily conceivable that improved plants obtained via ODM are therefore equally suitable. In addition, mutagenesis has the disadvantage of acting randomly throughout the plant genome, while ODM induce precise and targeted mutations.

\section{Antisense Technologies}

Antisense technologies rely on the insertion of antisense single stranded DNA (antisense oligodeoxynucleotides (asODNs) or double-stranded RNA (RNA interference) molecules into plant cells to prevent or drastically reduce translation of a specific protein. As the direct application to plant cells of asODNs or short interfering RNAs (siRNAs) enables the production of non-GM organisms (Lombardo et al., 2016 [27]). These forms of genetic material manipulation are technically compatible and strictly adherent with organic farming standards.

asODNs (typically composed of 12-25 nucleotides) anneal to specific complementary mRNAs, forming a DNA/RNA hybrid that prevents ribosomes to move along the messenger RNA (Crum et al., 1988 [28]) (hybridization arrest) or that is degraded by the enzyme RNase H (Miroshnichenko et al., 1988 [29]). The low cell-wall permeability has traditionally limited the development of inhibition via asODNs in plant biology studies; nevertheless, a growing interest arose when the uptake of synthetic asODNs was demonstrated to be enhanced in sugar solution, as the uptake probably occurs through sugar transporters (Sun et al., 2007; 2008; Xie et al., 2014 [30-32]). Similarly, patent application WO2013089614A1 [33] describes the use of an aqueous-sugar solution conveying an antisense oligodeoxinucleotide capable of hybridizing to a portion of mRNA transcribed from an 
essential plant gene, knocking it down, and thus acting as a herbicide. The contacting step is performed by spraying the plant with the aqueous solution, as proposed even in Xie et al. (2014 [32]).

Gene silencing by RNA interference (RNAi) has been typically achieved by introducing inverted repeat transgenes, resulting in double-stranded RNA transcripts (dsRNAs) or transgenes coding for self-complementary hairpin-RNA (hpRNA) (Senthil-Kumar and Mysore, 2010 [34]). dsRNAs are cleaved into RNA duplexes of 21-28 nucleotides by the Dicer enzyme. These short interfering siRNAs (in particular the guide RNAs) are incorporated into a nuclease complex (RISC) that degrades any mRNA sharing sequence homology (Younis et al., 2014 [35]). A recent non-transgenic embodiment provides the direct spraying of crude dsRNA-containing extracts on plants organs (Gan, et al., 2010; San Miguel and Scott, 2015 [36,37]), avoiding any plant transformation. This principle is also the basis of the BioDirect ${ }^{\mathrm{TM}}$ technology by Monsanto conceived for pest, weed, and disease control in crop plants.

\section{The Acceptance of Biotech Food}

Several surveys conducted in the last decade in the USA and Europe found that from $52 \%$ to $81 \%$ of the respondents would consume cisgenic food (even at a higher price if this implies an enhanced nutritional value), while this percentage drops to $14-33 \%$ with transgenic plants (Lusk and Sullivan, 2002; Schaart, 2004; Lusk and Rozan, 2006; Colson and Huffman, 2011; Mielby, 2011 [38-42]). However, it is realistic to think that organic consumers would oppose the approval of the use of plants obtained through technologies providing the insertion of foreign material in organic farming, while there is no clue to assert with equal confidence that they would be in any way contrary to the use of technically non-GM crops. It should, however, be emphasized that these plants would be totally unrecognizable from unmanipulated counterparts so that only an effective patent protection system and a mandatory labeling policy could limit their volunteer wide diffusion. These solutions are, however, ineffective to prevent long-distance gene flow via pollen dissemination.

\section{Conclusions}

The development of targeted and precise technologies, such as genome editing with engineered nucleases combined with cisgenesis, that do not provide the insertion of foreign genetic material into plant cells is likely to drastically modify consumers' perception of GM products in the next few years. This, together with the evidence that genetically engineered crops can have a positive impact on environmental sustainability by reducing reliance upon agrochemicals, could accelerate the acceptance and employment or these new categories of GM plants in organic farming, insofar as a consistent percentage of consumers of organic products will realistically remain in any case contrary to these biotechnologies since a common concern is that artificial genetic manipulation excludes a priori the concept of natural food and because of an ideological prejudice-or at least suspicion-towards GMOs. Nevertheless, the possibility of producing technically non-GM crops via ODM, and antisense approaches, should break down any remonstrance against the use of modern biotechnologies in organic farming.

Author Contributions: The authors contributed equally to the paper.

Conflicts of Interest: The authors declare no conflict of interest.

\section{References}

1. European Commission. Directive 2001/18/EC of the European Parliament and of the Council of 12 March 2001 on the deliberate release into the environment of genetically modified organisms and repealing Council Directive 90/220/EEC. Off. J. Eur. Union 2001, 106, 1-38.

2. European Food Safety Authority (EFSA). Scientific opinion addressing the safety assessment of plants developed through cisgenesis and intragenesis. EFSA J. 2012, 10, 2561.

3. Holme, I.B.; Wendt, T.; Holm, P.B. Intragenesis and cisgenesis as alternatives to transgenic crop development. Plant Biotechnol. J. 2013, 11, 395-407. [CrossRef] [PubMed] 
4. Schouten, H.J.; Krens, F.A.; Jacobsen, E. Do cisgenic plants warrant less stringent oversight? Nat. Biotech. 2006, 24, 753. [CrossRef] [PubMed]

5. Telem, R.S.; Wani, S.H.; Singh, N.B.; Nandini, R.; Sadhukhan, R.; Bhattacharya, S.; Mandal, N. Cisgenics-A Sustainable Approach for Crop Improvement. Curr. Genom. 2013, 14, 468-476. [CrossRef] [PubMed]

6. Hou, H.; Atlihan, N.; Lu, Z.X. New biotechnology enhances the application of cisgenesis in plant breeding. Front. Plant Sci. 2014, 5, 1-5. [CrossRef] [PubMed]

7. Gene Technology Regulations 2001. Statutory Rules 2001 No. 106 Made under the Gene Technology Act 2000. Available online: https://www.legislation.gov.au/Details/F2011C00732 (accessed on 5 May 2016).

8. Van Bueren, L.E.T.; Verhoog, H.; Tiemens-Hulscher, M.; Struik, P.C.; Haring, M.A. Organic agriculture requires process rather than product evaluation of novel breeding techniques. Njas-Wagen. J. Life Sci. 2007, 54, 401-412. [CrossRef]

9. James, C. Global Status of Commercialized Biotech/GM Crops: 2014. ISAAA Briefs No. 49. Available online: https: / / www.google.com/url?sa=t\&rct=j\&q=\&esrc=s\&source=web\&cd=1\&ved=0ahUKEwi21dv73uXMAh

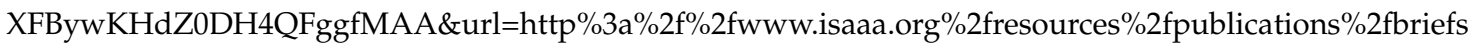
$\% 2 \mathrm{f} 49 \% 2$ fexecutivesummary $\% 2 \mathrm{fpdf} \% 2 \mathrm{fb} 49$-execsum-english.pdf\&usg=AFQjCNFm9BEvRpg2TXZm02uN0t X5b_Y5jg\&sig2=FB8g0LMqpMGuNjpIYUmZBQ\&bvm=bv.122129774,bs.1,d.bGg\&cad=rja (accessed on 5 May 2016).

10. GeneWatch UK and Greenpeace International. GM Contamination Register. Available online: http://www. gmcontaminationregister.org/ (accessed on 5 May 2016).

11. Holst-Jensen, A.; Bertheau, Y.; de Loose, M.; Grohmann, L.; Hamels, S.; Hougs, L.; Morisset, D.; Pecoraro, S.; Pla, M.; van den Bulcke, M.; et al. Detecting un-authorised genetically modified organisms (GMOs) and derived materials. Biotech. Adv. 2012, 30, 1318-1335. [CrossRef] [PubMed]

12. Peng, Y.; Clark, K.J.; Campbell, J.M.; Panetta, M.R.; Guo, Y.; Ekker, S.C. Making designer mutants in model organisms. Development 2014, 141, 4042-4054. [CrossRef] [PubMed]

13. Urnov, F.D.; Rebar, E.J.; Holmes, M.C.; Zhang, H.S.; Gregory, P.D. Genome editing with engineered zinc finger nucleases. Nat. Rev. Genet. 2010, 11, 636-646. [CrossRef] [PubMed]

14. Jiang, W.; Zhou, H.; Bi, H.; Fromm, M.; Yang, B.; Weeks, D.P. Demonstration of CRISPR/Cas9/sgRNA-mediated targeted gene modification in Arabidopsis, tobacco, sorghum and rice. Nucleic Acids Res. 2013. [CrossRef] [PubMed]

15. Zhang, Y.; Zhang, F.; Li, X.; Baller, J.A.; Qi, Y.; Starker, C.G.; Bogdanove, A.J.; Voytas, D.F. Transcription activator-like effector nucleases enable efficient plant genome engineering. Plant Physiol. 2013, 161, $20-27$. [CrossRef] [PubMed]

16. Xie, K.; Yang, Y. RNA-guided genome editing in plants using a CRISPRCas system. Mol. Plant 2013, 6, 1975-1983. [CrossRef] [PubMed]

17. Upadhyay, S.K.; Kumar, J.; Alok, A.; Tuli, R. RNA-guided genome editing for target gene mutations in wheat. G3 (Bethesda) 2013, 3, 2233-2238. [CrossRef] [PubMed]

18. Woo, J.W.; Kim, J.; Kwon, S.I.; Corvalan, C.; Cho, S.W.; Kim, H.; Kim, S.G.; Kim, S.T.; Choe, S.; Kim, J.S. DNA-free genome editing in plants with preassembled CRISPR-Cas9 ribonucleoproteins. Nat. Biotechnol. 2015, 33, 1162-1164. [CrossRef] [PubMed]

19. USDA. Reply to Request for Confirmation That Transgene-Free, CRISPR-Edited Mushroom Is Not a Regulated Article 2016. Available online: https://www.aphis.usda.gov/biotechnology/downloads/reg loi/15--321--01_air_response_signed.pdf (accessed on 5 May 2016).

20. Breyer, D.; Herman, P.; Brandenburger, A.; Gheysen, G.; Remaut, E.; Soumillion, P.; van Doorsselaere, J.; Custers, R.; Pauwels, K.; Sneyers, M.; et al. Genetic modification through oligonucleotide-mediated mutagenesis. A GMO regulatory challenge? Environ. Biosaf. Res. 2009, 8, 57-64. [CrossRef] [PubMed]

21. Sauer, N.J.; Mozoruk, J.; Miller, R.B.; Warburg, Z.J.; Walker, K.A.; Beetham, P.R.; Schöpke, C.R.; Gocal, G.F. Oligonucleotide-directed mutagenesis for precision gene editing. Plant Biotechnol. J. 2016, 14, 496-502. [CrossRef] [PubMed]

22. Zhu, T.; Mettenburg, K.; Peterson, D.J.; Tagliani, L.; Baszczynski, C. Engineering herbicide-resistant maize using chimeric RNA/DNA oligonucleotides. Nat. Biotechnol. 2000, 18, 555-558. [PubMed]

23. COGEM. New Techniques in Plant Biotechnology (COGEM Report CGM/061024-02). Commissie Genetische Modificatie, The Netherlands. 2006. Available online: http:/ /www.cogem.net/ (accessed on 5 May 2016). 
24. Food Standards Australia New Zealand. New Plant Breeding Techniques, Report of a Workshop; Food Standards Australia New Zealand: Canberra, Australia, 2013; p. 25.

25. Advisory Committee on Releases to the Environment. Advice on a Plant Breeding Technique Involving Oligo-Directed Mutagenesis: RTDSTM . Available online: http://webarchive.nationalarchives.gov.uk/ 20130822084033/http:/ /www.defra.gov.uk/acre/files/20110319-Cibus-advice.pdf (accessed on 5 May 2016).

26. German Federal Office of Consumer Protection and Food Safety (BVL). Stellungnahme der ZKBS zu Neuen Techniken für Die Pflanzenzüchtung 2015. Available online: http://www.bvl.bund.de/SharedDocs/ Downloads/06_Gentechnik/ZKBS/01_Allgemeine_Stellungnahmen_deutsch/04_Pflanzen/Neue_Techniken _Pflanzenzuechtung.pdf?_blob=publicationFile\&v=3 (accessed on 5 May 2016).

27. Lombardo, L.; Coppola, G.; Zelasco, S. New Technologies for Insect-Resistant and Herbicide-Tolerant Plants. Trends Biotechnol. 2016, 34, 49-57. [CrossRef] [PubMed]

28. Crum, C.; Johnson, J.D.; Nelson, A.; Roth, D. Complementary oligodeoxynucleotide mediated inhibition of tobacco mosaic virus RNA translation in vitro. Nucleic Acids Res. 1988, 16, 4569-4581. [CrossRef] [PubMed]

29. Miroshnichenko, N.A.; Karpova, O.V.; Morozov, S.Y.; Rodionova, N.P.; Atabekov, J.G. Translation arrest of potato virus X RNA in Krebs-2 cell-free system: RNase H cleavage promoted by complementary oligodeoxynucleotides. FEBS Lett. 1988, 234, 65-68. [CrossRef]

30. Sun, C.; Ridderstrale, K.; Höglund, A.S.; Larsson, L.G.; Jansson, C. Sweet delivery: Sugar translocators as ports of entry for antisense oligodeoxynucleotides in plant cells. Plant J. 2007, 52, 1192-1198. [CrossRef] [PubMed]

31. Sun, C.; Ghebramedhin, H.; Höglund, A.S.; Jansson, C. Antisense oligodeoxynucleotide inhibition as a potent diagnostic tool for gene function in plant biology. Plant Signal. Behav. 2008, 3, 328-330. [CrossRef] [PubMed]

32. Xie, Z.; Sundström, J.F.; Jin, Y.; Liu, C.; Jansson, C.; Sun, C. A selection strategy in plant transformation based on antisense oligodeoxynucleotide inhibition. Plant J. 2014, 77, 954-996. [CrossRef] [PubMed]

33. Sun, C.; Jansson, C.J. Usage of Oligonucleotides in Plant Biology. Patent WO/2013/089614A1, 20 June 2013.

34. Senthil-Kumar, M.; Mysore, K.S. RNAi in Plants: Recent developments and applications in agriculture. In Gene Silencing: Theory, Techniques and Applications; Catalano, A.J., Ed.; Nova Science Publishers, Inc.: New York, NY, USA, 2010; pp. 183-199.

35. Younis, A.; Siddique, M.I.; Kim, C.K.; Lim, K.B. RNA Interference (RNAi) Induced Gene Silencing: A Promising Approach of Hi-Tech Plant Breeding. Int. J. Biol. Sci. 2014, 10, 1150-1158. [CrossRef] [PubMed]

36. Gan, D.; Zhang, J.; Jiang, H.; Jiang, T.; Zhu, S.; Cheng, B. Bacterially expressed dsRNA protects maize against SCMV infection. Plant Cell Rep. 2010, 29, 1261-1268. [CrossRef] [PubMed]

37. San Miguel, K.; Scott, J.G. The next generation of insecticides: dsRNA is stable as a foliar-applied insecticide. Pest Manag. Sci. 2016, 72, 801-809. [CrossRef] [PubMed]

38. Lusk, J.L.; Sullivan, P. Consumers acceptance of genetically modified foods. Food Technol. 2002, 56, 32-37.

39. Schaart, J.G. Towards Consumer-Friendly Cisgenic Strawberries Which Are Less Susceptible to Botrytis Cinerea. Ph.D. Thesis, Wageningen University, Wageningen, The Netherlands, 2004.

40. Lusk, J.L.; Rozan, A. Consumers acceptance of intergenic foods. Biotechnol. J. 2006, 1, 1-2. [CrossRef] [PubMed]

41. Colson, G.; Huffman, W.E. Consumers' willingness to pay for genetically modified foods with product-enhancing nutritional attributes. Am. J. Agric. Econ. 2011, 93, 358-363. [CrossRef]

42. Mielby, H. Public Attitudes to Cisgenic Crops. Ph.D. Thesis, University of Copenhagen, Copenhagen, Denmark, 2011.

(C) 2016 by the authors; licensee MDPI, Basel, Switzerland. This article is an open access article distributed under the terms and conditions of the Creative Commons Attribution (CC-BY) license (http://creativecommons.org/licenses/by/4.0/). 